\title{
Adenosquamous carcinoma of the cervical oesophagus in a dog
}

\section{Francisca Maria Sousa Barbosa ${ }^{1}$ Natanael Félix Silva Filho ${ }^{2}$ Tolentino Lira Alcântra ${ }^{2}$ Gisele Castro Menezes ${ }^{1}$ Alex dos Santos $^{3}$ (D) Glaucia Denise Kommers ${ }^{3}$ (D) Ricardo Barbosa Lucena ${ }^{1^{*}}$ (1)}

\author{
${ }^{1}$ Hospital Veterinário, Universidade Federal da Paraíba (UFPB), 58397-000, Areia, PB, Brasil. E-mail: lucena.rb@gmail.com \\ "Corresponding author. \\ ${ }^{2}$ Clínica Veterinária Minha Cria, João Pessoa, PB, Brasil. \\ ${ }^{3}$ Laboratório de Patologia Veterinária, Universidade Federal de Santa Maria (UFSM), Santa Maria, RS, Brasil.
}

\begin{abstract}
A 9-year-old male Shih Tzu dog presented with a mass on the ventral region of the neck and developed ptyalism. Radiographs revealed a radiodense nodule located in the mid-third of the oesophagus compressing the trachea. Preoperative cytology showed large neoplastic cells with abundant vacuolated cytoplasm arranged in clusters. The nodule was removed by oesophagectomy and submitted for histopathology. Microscopically, the oesophageal mass was multilobulated and unencapsulated. It had a mixed cellular growth pattern with areas showing squamous and glandular differentiation. The squamous component of the tumor was formed by solid strands of neoplastic epithelial cells; many neoplastic cells had undergone central keratinization and sometimes formed keratin pearls. The deeper adenocarcinomatous portion of the tumor consisted of tubules filled with slightly basophilic mucinous material. Histological and immunohistochemical examination confirmed the diagnosis of primary adenosquamous carcinoma (ASC) of the esophagus. This is the first report of primary ASC of the cervical oesophagus in a dog.
\end{abstract}

Key words: oesophageal carcinoma, squamous cell carcinoma; adenocarcinoma, canine.

Carcinoma adenoescamoso do esôfago cervical em um cão

\begin{abstract}
RESUMO: Um cão Shih Tzu de nove anos de idade apresentou uma massa na região ventral do pescoço e desenvolveu ptialismo. As radiografias revelaram um nódulo radiodenso localizado no terço médio do esôfago que comprimia a traqueia. A citologia pré-operatória mostrou células neoplásicas grandes com citoplasma vacuolizado abundante, dispostas em aglomerados. O nódulo foi removido por esofagectomia e submetido à histopatologia. Microscopicamente, a massa esofágica era multilobulada e não encapsulada. Apresentava um padrão de crescimento celular misto, com áreas mostrando diferenciação escamosa e áreas de diferenciação glandular. O componente escamoso do tumor era formado por filamentos sólidos de células epiteliais neoplásicas; muitas células neoplásicas demonstravam queratinização central e, por vezes, formavam pérolas de queratina. A porção adenocarcinomatosa mais profunda do tumor consistia em túbulos preenchidos com material mucinoso levemente basofilico. O exame histológico e imunohistoquímico confirmaram o diagnóstico de carcinoma adenoescamoso primário do esôfago. No conhecimento dos autores, este é o primeiro relato de carcinoma adenoescamoso primário do esôfago cervical em um cão. Palavras-chave: carcinoma esofágico, carcinoma de células escamosas, adenocarcinoma, canino.
\end{abstract}

Oesophageal tumours are rare, accounting for less than $0.5 \%$ of all tumours in dogs and cats (UZAL et al., 2016). Squamous cell carcinomas (SCCs), fibrosarcomas, osteosarcomas, and leiomyomas are the more common types of primary esophageal tumor of dogs (MCCAW et al., 1980, RANEN et al., 2004a, RANEN et al., 2004b).

SCCs of the oesophagus are malignant tumors originating from the oesophageal stratified squamous epithelium, and occur infrequently in animals (UZAL et al., 2016), with the exception of oesophageal SSCs that affect cattle grazing on pastures invaded by Pteridium spp. (bracken fern) (LUCENA et al., 2011). Adenosquamous carcinoma of the esophagus that contains both adenocarcinoma and squamous cell carcinoma elements is even more unusual.

To date, there is only one case report of this type of tumor in a $\operatorname{dog}$ (OKANISHI et 
al., 2015) and a single case of such neoplasm in a cat (SHINOZUKA et al., 2001); in both cases, a diagnosis of adenosquamous carcinoma of the oesophagus was made. Oesophageal adenosquamous carcinomas $(\mathrm{OAC})$ are also considered very rare in humans, accounting for only $0.92 \%$ of all primary oesophageal carcinomas (TRIPATHI \& SWANSON, 2016). To our knowledge, there are no published reports of adenosquamous carcinoma of the cervical oesophagus in dogs. The present report aimed to describe in detail the clinical, cytological, and pathological characteristics of an OAC in a dog.

A 9-year-old male Shih Tzu dog was presented with a progressively growing mass on the ventral region of the neck. As this cervical mass increased in size, the dog started showing ptyalism which lasted 5 days, and fever of $40.1^{\circ} \mathrm{C}$. Physical examination findings included a palpable firm nodule on the ventral cervical region and slightly enlarged mandibular lymph nodes. Radiographs revealed a radiodense nodule located in the mid-third of the oesophagus compressing the trachea (Figure 1A). Preoperative cytology showed large neoplastic cells which had abundant vacuolated cytoplasm and were arranged in clusters (Figure 1B). Marked anisocytosis and anisokaryosis were also noted (Figure 1C), and the diagnosis of primary oesophageal carcinoma was made.

The nodule was removed by oesophagectomy. The free resection margin was more than $1 \mathrm{~cm}$. Grossly, the excised mass was firm, had an irregular surface measured $4.0 \mathrm{~cm} \mathrm{x}$ $3.0 \mathrm{~cm} \times 2.5 \mathrm{~cm}$ and partially obstructed the lumen of the oesophagus. On cut surface it was white and multilobulated (Figure 1D).

The excised mass was fixed in $10 \%$ neutral buffered formalin, processed routinely for histological examination, and embedded into paraffin blocks. Sections of the mass were stained with haematoxylin and eosin (HE), and examined histologically. Serial sections of the oesophageal mass were stained with

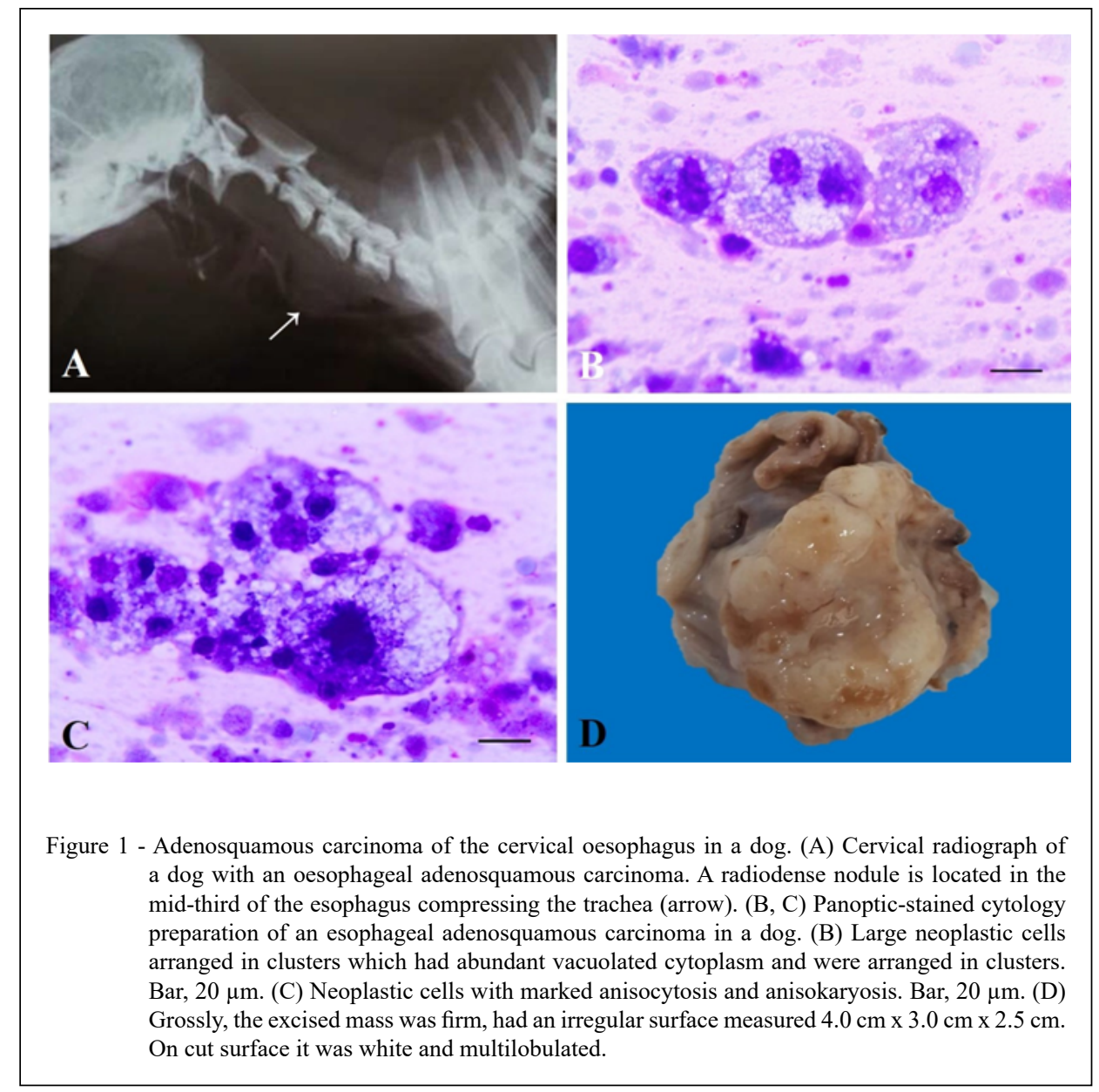

Ciência Rural, v.50, n.7, 2020. 
periodic acid-Schiff (PAS) and Alcian blue at $\mathrm{pH}$ 2.5. Immunohistochemistry (IHC) was performed with the polymer method (EasyLinkOne, EasyPath) using a rabbit polyclonal anti-bovine pan-cytokeratin antibody (Dako, Carpinteria, California, USA; 1 in 2,000 dilution) modified from Masuda et al. (2011).

Microscopically, the oesophageal nodule was multilobulated and unencapsulated. This neoplastic mass exhibited a mixed neoplastic growth pattern showing areas of squamous and glandular differentiation (Figure 2A). The squamous component was formed by solid strands of neoplastic epithelial cells that extended from the epithelial lining of the oesophageal mucosa and invaded the underlying submucosa. Tumor cells had scant cytoplasm with indistinct borders, and large, ovoid, vesicular nuclei with one or more distinct nucleoli. Many neoplastic cells had undergone central keratinization and sometimes formed keratin pearls (Figure 2B).

The deeper area of the tumor had a glandular pattern, extended through the submucosa and invaded the muscular and serous layers. This component of the neoplasm consisted of tubules filled with slightly basophilic, Alcian blue- and PASpositive mucinous material. Neoplastic cells forming the glandular component of the oesophageal neoplasm were cuboidal to polyhedral, and showed moderate to severe pleomorphism. The majority of the tumor cells had a moderate to abundant amount of slightly vacuolated cytoplasm (Figure 2C). In the more solid portions of the neoplasm, tumor cells had a more dense, intensely eosinophilic cytoplasm. Nuclei were oval, vesicular, with one or more distinct nucleoli. There were numerous atypical mitotic figures in both squamous and glandular components of the tumor. Solid areas of the neoplasm showed up to 20 atypical mitoses per high-power field (HPF). Tumor cells were supported by a delicate fibrovascular stroma. Marked desmoplastic reaction was seen in some areas of the stroma. There were remnants of oesophageal submucosal glands scattered throughout the tumor.

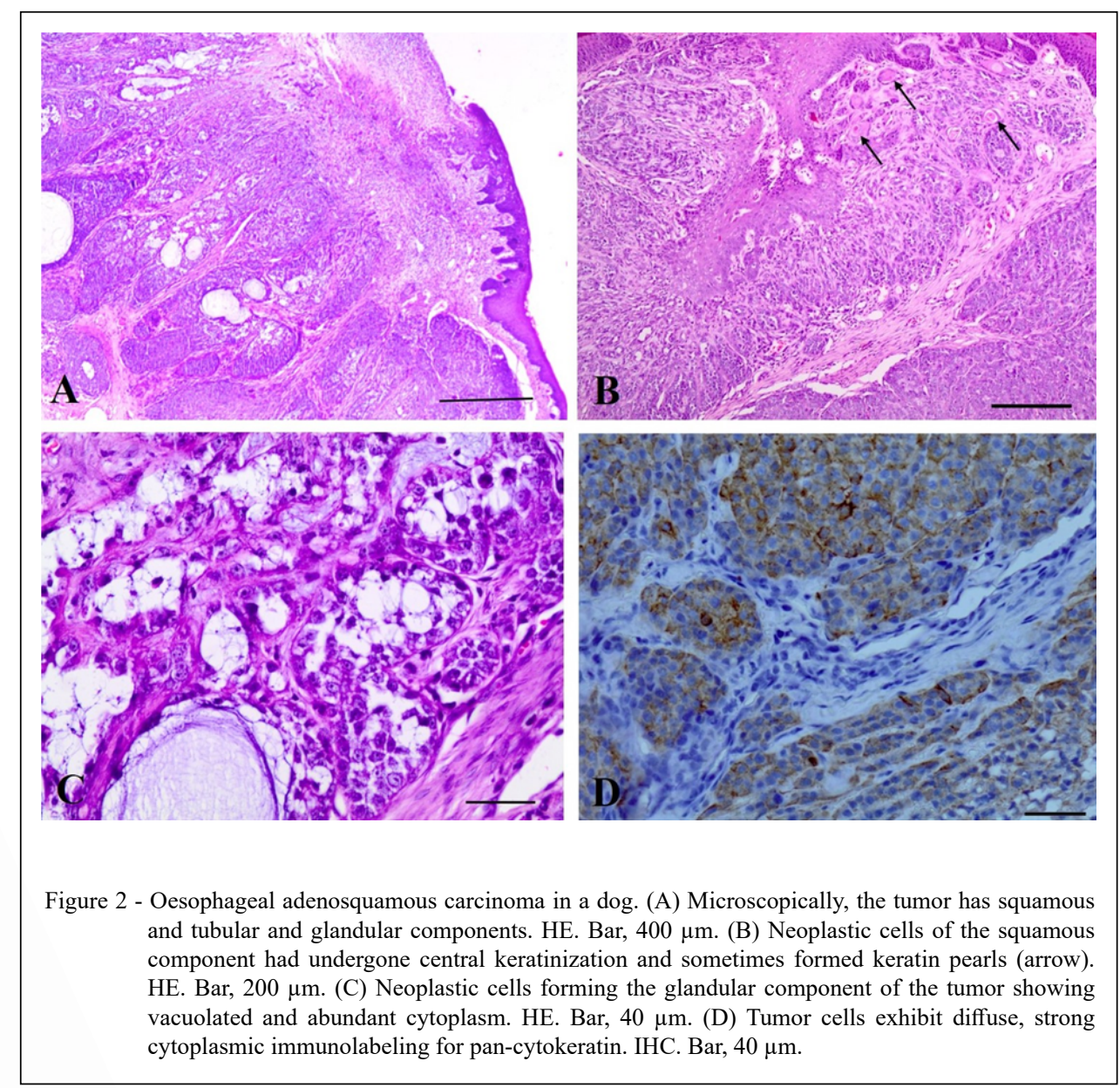

Ciência Rural, v.50, n.7, 2020. 
The central part of the tumor had multiple necrotic foci. There were extensive areas of ulceration of the oesophageal mucosa. Tumor cells exhibited diffuse, strong cytoplasmic immunolabeling for pancytokeratin (Figure 2D).

A diagnosis of primary adenosquamous carcinoma (ASC) of the oesophagus was made by histopathological and immunohistochemical findings, and no recurrences were noted during the follow-up period of one year after surgery.

Malignant primary neoplasms of the canine oesophagus occur more often than their benign counterparts. Fibrosarcomas and osteosarcomas associated with the presence of the spirurid nematode Spirocerca lupi in the thoracic esophagus (UZAL et al., 2016) are the oesophageal tumors most frequently reported in dogs. In contrast, oesophageal metastatic tumors are three times more common than primary tumors of the oesophagus. A number of tumors may metastasize to the oesophagus including primary tumors that occur in areas adjacent to the oesophagus such as neoplasms arising in the stomach, thymus, thyroid gland, or at base of the heart as well as those originating in the mammary gland or multicentric lymphoma (RIDGWAY \& SUTER, 1979). In the present case other tumors were not found elsewhere in the body.

This is an unusual malignant oesophageal neoplasm in which elements of infiltrating squamous cell carcinoma (SCC) and adenocarcinoma (AC). A comprehensive literature review revealed that to date there is only one published case report of an oesophageal adenoquamous carcinoma in the caudal (thoracic) oesophagus of a dog (OKANISHI et al., 2015) and a cat (SHINOZUKA et al., 2001). Purely glandular oesophageal tumors are also rare in animals and humans. In humans, primary adenocarcinomas of the upper (cervical) oesophagus arise from ectopic islands of normal gastric mucosa located within the oesophageal wall and are extremely rare (RIDDIOUGH, 2017). In contrast, oesophageal hyperplasia, metaplasia and neoplasia of the caudal (thoracic) oesophagus are relatively common in humans (DEMEESTER \& DEMEESTER, 2000). These are adaptative responses of the esophageal mucosa to chronic inflammation secondary to gastrooesophageal reflux (NAINI et al., 2016). Metaplasia of the oesophageal mucosa (Barrett's oesophagus) may give rise to adenocarcinoma of the lower oesophagus (HAYAKAWA et al., 2016).

Causes of esophageal cancer in dogs are unknown. To date, there are only two published case reports of naturally occurring metaplastic transformation of the squamous epithelium of the mucosa of the caudal oesophagus of dogs into mucinous columnar epithelium. One of the cases was an adenomatous polyp with intestinal metaplasia (Barrett's oesophagus) (GIBSON et al., 2010) and the other one was an adenocarcinoma arising in Barrett's oesophagus (CHAMBERS et al., 2017). In an experimental study, gastroesophageal reflux was surgically induced in 50 dogs that underwent cardiectomy or gastrectomy; 24 out of 50 dogs developed Barrett's oesophagus. In nine dogs, Barrett's oesophagus progressed to moderate dysplasia of the oesophageal mucosa. In two dogs, an oesophageal adenocarcinoma originated from these dysplastic lesions 60 months post-surgery (KAWAURA et al., 2001). In the present case, the neoplasm was located in the cranial (cervical) third of the oesophagus. Typically, gastroesophageal reflux is associated with malignant neoplasms of the caudal third of the oesophagus. We; therefore, ruled out acid reflux as a possible cause for the development of a malignant tumor of the oesophagus in this dog.

It is concluded that esophageal ASC can also develop in the upper oesophagus of dogs. Further studies are needed to clarify the epidemiology, etiology, clinicopathological characteristics and pathogenesis of canine oesophageal ASC.

\section{BIOETHICS AND BIOSSECURITY COMMITTEE APPROVAL}

The authors of this article declared, for all due purposes, the project that gave rise to the present data of the same has not been submitted for evaluation to the Ethics Committee of the University / Research Institute "Universidade Federal da Paraíba (UFPB)", but we are aware of the content of the Brazilian resolutions of the National Council for Control of Animal Experimentation - CONCEA"http://www.mct.gov. br/index.php/content/view/310553.html" if it involves animals.

This is a case report of a sick dog that was brought to UFPB by the owner. Therefore, the diagnostic procedures were necessary and are part of the diagnostic routine. Thus, the authors assume full responsibility for the presented data and are available for possible questions, should they be required by the competent authorities.

\section{DECLARATION OF CONFLICT OF INTERESTS}

The authors declare no conflict of interest. The funding sponsors had no role in the design of the study; in the collection, analyses, or interpretation of data; in the writing of the manuscript, and in the decision to publish the results.

\section{AUTHORS' CONTRIBUTIONS}

All authors contributed equally for the conception and writing of the manuscript. All authors critically revised the manuscript and approved the final version. 


\section{REFERENCES}

CHAMBERS, J. K. et al. Adenocarcinoma of Barrett's esophagus in a dog. Journal of Toxicology Pathology. v.30, n.3, p.239-243, 2017. Available from: <https://www.ncbi. nlm.nih.gov/pmc/articles/PMC5545677/pdf/tox-30-239.pdf>. Accessed: Jan. 20, 2019.

DEMEESTER, S. R; DEMEESTER, T. R. Columnar mucosa and intestinal metaplasia of the esophagus: fifty years of controversy. Annals of surgery, v.231, n.3, p.303-21, 2000. Available from: $<$ https://www.ncbi.nlm.nih.gov/pmc/articles/PMC1421001/>. Accessed: Jan. 20, 2019.

GIBSON C. J. et al. Adenomatous polyp with intestinal metaplasia of the esophagus (Barrett esophagus) in a dog. Veterinary Pathology, v.47, n.1, p.116-119, 2010. Available from: <https://www.ncbi.nlm.nih.gov/pubmed/20080491>. Accessed: Jan. 20, 2019.

HAYAKAWA, Y. et al. Oesophageal adenocarcinoma and gastric cancer: should we mind the gap? Nature Reviews Cancer, v.16, n.5, p.305-318, 2016. Available from: <https://www.ncbi.nlm.nih. gov/pubmed/27112208>. Accessed: Jan. 20, 2019.

KAWAURA, Y. et al. Immunohistochemical study of p53, c-erbB-2, and PCNA in barrett's esophagus with dysplasia and adenocarcinoma arising from experimental acid oralkaline reflux model. Journal of Gastroenterology, v.36, n.9, p.595600, 2001. Available from: <https:/www.ncbi.nlm.nih.gov/ pubmed/11578062>. Accessed: Jan. 20, 2019.

LUCENA R. B. et al. A retrospective study of 586 tumours in Brazilian cattle. Journal Comparative Pathology, v.145, n.1 p.20-24, 2011. Available from: <https:/www.ncbi.nlm.nih.gov/ pubmed/21247583>. Accessed: Jan. 20, 2019.

MCCAW, D. et al. (1980) Squamous cell carcinoma of the esophagus in a dog. Journal of the American Animal Hospital Association, 16, 561-563, 1980.

NAINI, B. V. et al. (2016) Barrett's Esophagus: a comprehensive and contemporary review for pathologists. The American Journal of Surgical Pathology, v.40, n.5, e45-66. Available from:
$<$ https://www.ncbi.nlm.nih.gov/pubmed/26813745>. Accessed: Jan. 20, 2019.

OKANISHI, $\mathrm{H}$. et al. Adenosquamous carcinoma of the oesophagus in a dog. The Journal Small Animal Practice, v.56, n.8, 521-523, 2015. Available from: <https://www.ncbi.nlm.nih. gov/pubmed/25622695>. Accessed: Jan. 20, 2019.

RANEN E. et al. Spirocercosis-associated esophageal sarcomas in dogs. A retrospective study of 17 cases (1997-2003). Veterinary Parasitology, v.30, n.119 (2-3), p.209-221, 2004a. Available from: $<$ https://www.ncbi.nlm.nih.gov/pubmed/14746980>. Accessed: Jan. 20, 2019

RANEN E. et al. Partial esophagectomy with single layer closure for treatment of esophageal sarcomas in 6 dogs. Veterinary Surgery, v.33, n.4, p.428-434, 2004b. Available from: <https://www.ncbi. nlm.nih.gov/pubmed/15230849>. Accessed: Jan. 20, 2019.

RIDDIOUGH G. E. et al. Gastric adenocarcinoma of the upper oesophagus: A literature review and case report. International Journal of Surgery Case Reports, v.30, n.1, p205-214, 2017. Available from: <https://europepmc.org/abstract/med/28086198>. Accessed: Jan. 20, 2019.

RIDGWAY, R. L; SUTER, P. F. Clinical and radiographic signs in primary and metastatic oesophageal neoplasms of the dog. Journal of the American Veterinary Medical Association. v.174, n.7 p.700-704, 1979. Available from: <http://europepmc.org/abstract/ med/429231>. Accessed: Jan. 20, 2019.

SHINOZUKA J. et al. Esophageal adenosquamous carcinoma in a cat. The Journal of Veterinary Medical Science. V.63, n.1, p.91-93, 2001. Available from: <https://www.ncbi.nlm.nih.gov/ pubmed/11217072>. Accessed: Jan. 20, 2019.

TRIPATHI, M; SWANSON, P. E. Rare tumors of esophageal squamous mucosa. Annals of the New York Academy of Sciences, v.1381, n.1 p.122-132, 2016. Available from: <https:// europepmc.org/abstract/med/27310830>. Accessed: Jan. 20, 2019.

UZAL F. A. et al. Alimentary system. In: Maxie MG, ed. Jubb, Kennedy, and Palmer's.Pathology of Domestic Animals, 6th Edit, Vol. 2, Philadelphia, PA: Elsevier, 2016. p. 2-112. 